\title{
Land Utilization and Cropping Pattern in Beed District of Maharashtra
}

\author{
R.A. Gaikwad*, K.V. Deshmukh and R.D. Shelke \\ Department of Agricultural Economics, College of Agriculture Latur, Vasantrao Naik \\ Marathwada Krishi Vidyapeeth, Parbhani (M.S.), India \\ *Corresponding author
}

Ke y w o r d s
$\begin{aligned} & \text { Land utilization } \\ & \text { pattern and } \\ & \text { cropping pattern of } \\ & \text { Beed district }\end{aligned}$
Article Info
$\begin{aligned} & \text { Accepted: } \\ & \text { 15 September } 2018 \\ & \text { Available Online: } \\ & 10 \text { October } 2018\end{aligned}$

A B S T R A C T

Agriculture mainly depends on the natural resource that is land. Land availability, type of land and soil type are the main determinants of crops to be grown. Land utilization pattern and cropping pattern differs from one region to other. So, the present study was undertaken to analyse the land use pattern and cropping pattern in Beed district of Maharashtra. Study was based on secondary data. Data were analyses using statistical tools like Functional analysis and tabular analysis. Results of the study revealed that, in case of land utilization pattern, Land under forest during 2000-01 was 2.10 per cent and in 2015-16 increased to 2.13 per cent and percentage change during 2015-16 over 2000-01 was 1.18.under Net sown area 66.61 per cent area in 2000-01 while it was 73.17 per cent in 2015-16. It shows that there was increase in area by 6.86 per cent. Area sown more than once in 2000-01 was 26.07 per cent and it was 24.64 per cent in 2015-16 and percentage change was -5.11 per cent. The total gross cropped area in 2000-01 was 91.96 per cent while in 2015-16 it was 97.33 per cent in 2015-16 and percentage change was 5.32 per cent. Area under food grains in 2000-01 was 75.37 per cent while in 2015-16 it was 64.01 per cent and the percentage change was -5.60 per cent of which the percentage change of cereals and pulses were -13.83 and 42.38 per cent, respectively. Area under maize and cotton were changed by 175 per cent and 291.62 per cent, respectively. Change in cropping pattern in 2015-16 over 2000-01 was more in soybean and Cotton i.e. 1218.35 per cent and 291.62 per cent.

\section{Introduction}

Agriculture is the main occupation and backbone in developing country like India and is a bottleneck in the economic development of the country. At present, Agriculture sector contributes 14.5 per cent in national income in India and it sustains 60 per cent of population for their lively hood. The share of agriculture sector in national economy is decreasing but not the population dependent on it. Agriculture development plays an important role in the growth of other sectors of economy. Agriculture development means process through which shift takes place from stage of traditional agriculture to stage of modernized agriculture. It includes higher level of food grains, fruits, and vegetables and other farm products, high income and better standard of living.

Maharashtra plays a major role in economic development of India. In India 9.29 per cent of the total population which occupied by 
Maharashtra is currently 11.24 crore people with the literacy rate 82.9 per cent. The geographical area of Maharashtra is 307713 $\mathrm{km}^{2}$; approximately 140-145 lakh ha of land is cultivated in the Kharif season and 60-65 lakh ha in rabi season. The production of food grain in 2012-2013 expected to register decrease of 23 per cent with the production of 118.09 lack metric tonnes. Hence it was felt necessary to study "Land utilization and cropping pattern of Beed district of Maharashtra"

\section{Materials and Methods}

Beed district was purposively selected for present study because Beed district has made progress in agricultural development due to increase of irrigation facility through Manjra dam, Bindusara dam, Majalgaon dam Study is evaluated the agricultural development that has been achieve so far during X and XII five year plan in Beed district The various selected parameters are land utilization, cropping pattern. In analytical techniques tabular analysis and functional analysis such as linear and compound growth rate was used to analyze data for the study secondary data for 15 year (from 2000-01 to 2015-16) ware collected from District Statistical office.

\section{Results and Discussion}

\section{Land utilization patter in Beed district}

The results are presented in table 1 which indicated that the area under forest was 225.00 hectares i.e. 2.10 per cent of total geographical area in 2000-01, which increased to 228.00 hectares in 2015-16, i.e. it increased by 1.18 per cent over the base year.

Barren and uncultivable land increased from 1.73 per cent to 2.36 per cent during the period from 2000-01 to 2015-16. Land under non-agricultural use was decreased from
420.00 to 412.00 hectares during the period from 2000-01 to 2015-16 i.e.3.93 per cent to 3.85 per cent. The cultivable wasteland area showed increase, it was 300.00 hectares in 200001 to 369.00 hectares in 2015 - 16 i.e. 3.45 per cent of the total geographical area. The area under permanent pastures decreased and land under miscellaneous trees decreased over a period. Permanent pastures decreased from 320.00 hectares to 307.00 hectares during the period from 2000-01 to 2015-16.

The current fallow land was 678.00 hectare i.e. 6.34 per cent of the total geographical area in 2000-01, which increased to 938.00 hectare in 2015-2016 i.e. 8.77 per cent of total geographical area. The net sown area was 7118.00 hectares i.e. 66.61per cent in 200001 , which increased to 7819.00 hectares i.e. 73.17 per cent in 2015-16. The area sown more than once increased was 2786.00 hectare during 2000-01 and later showed decline was 2634.00 in 2015-2016. The gross cropped area was 9827.00 hectares during the year 2000-01 i.e. 91.96 per cent, which indicate significant increase to 10406.00 hectares i.e. 97.33 per cent during year 2015-16.

\section{Cropping pattern of Beed district}

The result are presented in table 2 which shows that, the area under Rice decreased from 24.00 hectares 2000-01 to 3.00 hectares in 2015-16. The area under Wheat increased from 430.00 hectares in $2000-01$ to 480.00 hectares in $2015-16$ i.e. from 4.37 per cent to 4.61 per cent of the gross cropped area. The area under Jowar decreased from 2000-01 to 2015-16 i.e. 35.20 to 28.94 per cent to the gross crop area. The area under Bajra showed increased from 2136.00 hectares in 2000-01 but there was drastic decrease was 1276.00 hectares during year 2015-16. Total cereals showed decline from 2000-01 to 2015-16 it was 6143.00 to 4963.00 hectares over the base year. 
Table.1 Land utilization pattern in Beed (2000-01 to 2015-16)

\begin{tabular}{|c|c|c|c|c|}
\hline & & & & (Area in " 00 " \\
\hline Sr. No. & Particulars & 2000-2001 & 2015-2016 & $\begin{array}{l}\text { Percentage } \\
\text { change }\end{array}$ \\
\hline 1 & Geographical area & $\begin{array}{c}10686.00 \\
(100)\end{array}$ & $\begin{array}{c}10686.00 \\
(100)\end{array}$ & 00 \\
\hline 2 & Forest & $\begin{array}{c}225.00 \\
(2.10)\end{array}$ & $\begin{array}{r}228.00 \\
(2.13)\end{array}$ & 1.18 \\
\hline 3 & Barren and uncultivable land & $\begin{array}{l}185.00 \\
(1.73)\end{array}$ & $\begin{array}{c}253.00 \\
(2.36)\end{array}$ & 26.11 \\
\hline 4 & $\begin{array}{l}\text { Land under non-agricultural } \\
\text { use }\end{array}$ & $\begin{array}{r}420.00 \\
(3.93)\end{array}$ & $\begin{array}{c}412.00 \\
(3.85)\end{array}$ & -1.74 \\
\hline 5 & Cultivable waste & $\begin{array}{l}300.00 \\
(2.80)\end{array}$ & $\begin{array}{c}369.00 \\
(3.45)\end{array}$ & 27.06 \\
\hline 6 & Permanent Pastures & $\begin{array}{l}320.00 \\
(2.99)\end{array}$ & $\begin{array}{l}307.00 \\
(2.87)\end{array}$ & -9.40 \\
\hline 7 & Land under Miscellaneous tree & $\begin{array}{l}21.00 \\
(0.19)\end{array}$ & $\begin{array}{l}13.00 \\
(0.12)\end{array}$ & -38.09 \\
\hline 8 & Current fallow & $\begin{array}{l}678.00 \\
(6.34)\end{array}$ & $\begin{array}{r}938.00 \\
(8.77)\end{array}$ & 41.52 \\
\hline 9 & Other fallow & $\begin{array}{l}390.00 \\
(3.64)\end{array}$ & $\begin{array}{c}412.00 \\
(3.85)\end{array}$ & 22.65 \\
\hline 10 & Net sown area & $\begin{array}{l}7118.00 \\
(66.61)\end{array}$ & $\begin{array}{l}7819.00 \\
(73.17)\end{array}$ & 6.86 \\
\hline 11 & Area sown more than Once & $\begin{array}{c}2786.00 \\
(26.07)\end{array}$ & $\begin{array}{r}2634.00 \\
(24.64)\end{array}$ & -5.11 \\
\hline 12 & Gross cropped area & $\begin{array}{c}9827.00 \\
(91.96)\end{array}$ & $\begin{array}{c}10406.00 \\
(97.33)\end{array}$ & 5.32 \\
\hline
\end{tabular}


Table.2 Cropping pattern in Beed district (2000-01 to 2015-16)

\begin{tabular}{|c|c|c|c|c|}
\hline $\begin{array}{l}\text { Sr. } \\
\text { No. }\end{array}$ & Particulars & 2000-2001 & 2015-2016 & Percentage Change \\
\hline 1 & Rice & $\begin{array}{l}24.00 \\
(0.27)\end{array}$ & $\begin{array}{c}3.00 \\
(0.02)\end{array}$ & -83.33 \\
\hline 2 & Jowar & $\begin{array}{c}3460.00 \\
(35.20)\end{array}$ & $\begin{array}{c}3012.00 \\
(28.94)\end{array}$ & -14.35 \\
\hline 3 & Maize & $\begin{array}{l}78.00 \\
(0.79)\end{array}$ & $\begin{array}{l}172.00 \\
(1.65)\end{array}$ & 175 \\
\hline 4 & Wheat & $\begin{array}{c}430.00 \\
(4.37)\end{array}$ & $\begin{array}{c}480.00 \\
(4.61)\end{array}$ & 47.10 \\
\hline 5 & Bajra & $\begin{array}{c}2136.00 \\
(21.73)\end{array}$ & $\begin{array}{c}1276.00 \\
(12.26)\end{array}$ & -31.75 \\
\hline 6 & Total cereal & $\begin{array}{l}6128.00 \\
(62.51)\end{array}$ & $\begin{array}{r}4943.00 \\
(47.69)\end{array}$ & -13.87 \\
\hline 7 & Red gram & $\begin{array}{c}534.00 \\
(5.43)\end{array}$ & $\begin{array}{c}723.00 \\
(6.94)\end{array}$ & 8.61 \\
\hline 8 & Green gram & $\begin{array}{c}174.00 \\
(1.77)\end{array}$ & $\begin{array}{l}66.00 \\
(0.63)\end{array}$ & -67.62 \\
\hline 9 & Black gram & $\begin{array}{l}130.00 \\
(1.32)\end{array}$ & $\begin{array}{l}203.00 \\
(1.95)\end{array}$ & 43.98 \\
\hline 10 & Gram & $\begin{array}{c}269.00 \\
(9.61)\end{array}$ & $\begin{array}{l}706.00 \\
(6.78)\end{array}$ & 171.03 \\
\hline 11 & Total pulses & $\begin{array}{c}1107.00 \\
(12.86)\end{array}$ & $\begin{array}{c}1698.00 \\
(16.41)\end{array}$ & 65.01 \\
\hline 12 & Sesamum & $\begin{array}{l}99.00 \\
(1.00)\end{array}$ & $\begin{array}{l}32.00 \\
(0.30)\end{array}$ & -60.46 \\
\hline 13 & Sunflower & $\begin{array}{l}323.00 \\
(3.28)\end{array}$ & $\begin{array}{l}21.00 \\
(0.04)\end{array}$ & -92.77 \\
\hline 14 & Soybean & $\begin{array}{l}33.00 \\
(0.33)\end{array}$ & $\begin{array}{l}1451.00 \\
(13.94)\end{array}$ & 1218.35 \\
\hline 15 & Linseed & $\begin{array}{l}60.00 \\
(0.61)\end{array}$ & $\begin{array}{l}7.00 \\
(0.06)\end{array}$ & -90.41 \\
\hline 16 & Rapeseed and mustard & $\begin{array}{c}6.00 \\
(0.06)\end{array}$ & $\begin{array}{c}2.00 \\
(0.01)\end{array}$ & -66.66 \\
\hline 17 & Groundnut & $\begin{array}{l}159.00 \\
(1.61)\end{array}$ & $\begin{array}{l}184.00 \\
(1.76)\end{array}$ & -2.53 \\
\hline 18 & Total Oilseed & $\begin{array}{l}680.00 \\
(10.54)\end{array}$ & $\begin{array}{l}1697.00 \\
(16.57)\end{array}$ & 65.01 \\
\hline 19 & Cotton & $\begin{array}{l}829.00 \\
(8.43)\end{array}$ & $\begin{array}{c}3441.00 \\
(33.06)\end{array}$ & 291.62 \\
\hline 20 & Sugarcane & $\begin{array}{c}340.00 \\
(3.45)\end{array}$ & $\begin{array}{c}361.00 \\
(3.46)\end{array}$ & 16.55 \\
\hline 21 & Total food grain & $\begin{array}{c}7407.00 \\
(75.37)\end{array}$ & $\begin{array}{c}6661.00 \\
(64.01)\end{array}$ & -5.60 \\
\hline 22 & Gross cropped area & $\begin{array}{c}9827.00 \\
(100)\end{array}$ & $\begin{array}{c}10406.00 \\
(100)\end{array}$ & 5.32 \\
\hline
\end{tabular}




\section{Int.J.Curr.Microbiol.App.Sci (2018) 7(10): 2094-2100}

Table.3 Growth rate of land utilization pattern

\begin{tabular}{|c|c|c|c|c|c|c|c|c|c|c|}
\hline \multirow[t]{2}{*}{ Sr. No. } & \multirow[t]{2}{*}{ Particulars } & \multicolumn{6}{|c|}{ LGR } & \multirow{2}{*}{\multicolumn{3}{|c|}{ CGR }} \\
\hline & & \multicolumn{3}{|c|}{ Over the base year } & \multicolumn{3}{|c|}{ Over the average } & & & \\
\hline 1 & Forest & 0.05 & 0.03 & 0.1 & 0.05 & 0.03 & 0.71 & 0.05 & 0.03 & 0.09 \\
\hline 2 & $\begin{array}{l}\text { Barren and uncultivable } \\
\text { land }\end{array}$ & 0.99 & 2.53 & $2.24 * *$ & 0.96 & 2.21 & $1.99 * *$ & 0.96 & 2.31 & 2.00 \\
\hline 3 & $\begin{array}{l}\text { Land under non-agricultural } \\
\text { use }\end{array}$ & $0.18 * *$ & $-0.04 *$ & $-0.14 *$ & $-0.18 * *$ & $-0.04 *$ & $-0.14 *$ & -0.18 & -0.04 & -0.14 \\
\hline 4 & Cultivable waste land & $1.98 * *$ & $-0.13 * *$ & 2.49 & $1.91 * *$ & $-0.11 * *$ & 2.09 & 1.87 & -0.12 & 2.15 \\
\hline 5 & Permanent pastures & $-0.50 * *$ & $-1.32 * *$ & 1.11 & $-0.51 * *$ & $-1.13 * *$ & 1.05 & -0.51 & -1.23 & 1.04 \\
\hline 6 & $\begin{array}{l}\text { Land under misc trees, } \\
\text { grooves not included in } \\
\text { area sown }\end{array}$ & $-4.19 *$ & $-0.55 * *$ & $-3.09 * *$ & $-4.69 *$ & $-0.63 * *$ & $-4.07 * *$ & -4.70 & -0.61 & -3.89 \\
\hline 7 & Current fallow & $4.45 * *$ & -0.53 & $3.80 * *$ & $3.99 * *$ & -0.47 & $2.94 * *$ & 14.03 & -0.48 & 3.11 \\
\hline 8 & Other fallow & $3.54 * *$ & -0.62 & $1.97 * *$ & $3.28 * *$ & -0.61 & $1.69 * *$ & 3.27 & -0.74 & 1.73 \\
\hline 9 & Net sown area & $0.60 * *$ & $0.52 *$ & $0.51 * *$ & $0.59 * *$ & $0.51 *$ & $0.49 * *$ & 0.59 & 0.51 & 0.49 \\
\hline 10 & Area sown more than once & $-0.70 * *$ & -0.03 & $-0.39 * *$ & $-0.72 * *$ & -0.03 & $-0.41 * *$ & -0.72 & -0.3 & -0.41 \\
\hline 11 & Gross cropped area & $0.67 *$ & $0.45 * *$ & $0.37 * *$ & $0.66 *$ & $0.46 * *$ & $0.36 * *$ & 0.65 & 0.46 & 0.36 \\
\hline
\end{tabular}

Note: **Significant at 1 per cent $*$ Significant at 5 per cent 
Area under red gram was 534.00 hectares in 2000-01 and increased up to 723.00 hectares in $2015-16$ that is from 5.43 per cent to 6.94 per cent during the year 2000-01 to 2015-16. In addition, area under Green gram declined from 2000-01 to 2015-16 it was 174.00 to 66.00 hectares over the base year. Black gram increased from 130.00 hectares to 203.00 hectares during 2000-01 to 2015-16 i.e. from 1.32 per cent to 1.95 per cent2015-16.Total oilseeds increased from 1036.00 hectares to 1725.00 hectares during 2000-01 to 2015-16. Common oilseeds showed decreasing trend. The area under Soybean was 33.00 hectares in 2000-01 later on it is increased to 1451.00 hectares in 2015-16. Area under sunflower was 323.00 hectares in 2000-01 later on it was decreased to 21.00 hectares in 2015-16.Area under Sugarcane showed tremendous increased. It was 340.00 hectares in 2000-01 and increased up to 361.00 hectares in 201516. Area under cotton showed, increasing trend $2000-01$ to $2015-16$ it was 829.00 to 3441.00 hectares. It can be seen from the table that the area under commercial crops is increasing viz., cotton except Sugarcane. The changes in acreages under major crops during the period from 2000-01 to 2015-16

\section{Growth rate of land utilization pattern}

The result was depicted in table 3 which indicated that, the Barren and uncultivable land was significant at 1 per cent for overall period respectively. Cultivable waste land was significant at 1 per cent for I period and negative significant at 5 per cent for II period. Area under Permanent pastures was negative significant at 1 per cent for I period and period II. Land under misc trees, grooves not included in area sown was negative significant at 5 per cent for I period and period II, overall period was negative significant at 5 per cent. Area under Current fallow was significant at 1 per cent for I period and significant at 1 per cent for overall period. The other fallow was significant at 1 per cent for I period and significant at 1 per cent for overall period. The Net sown area was significant at 1 per cent for I period, overall period and significant at 5 per cent for II period. Area sowed more than once was negative significant at 1 per cent for I period and overall period. The Gross cropped area was significant at 5 per cent for I period and significant at 1 per cent for II period and overall period. Forest was non-significant for overall period, respectively.

It is concluded from the study that agriculture land in Beed district is declining due to more exhaustive cultivation of land by using more amount of chemicals. To meet food security, forest land has been brought under cultivation. Farmers should use the organic components in agriculture land and can bring back the land to its original status. By doing this cropping intensity can also be increased. By growing two to three crops in a year farmers can increase cropping intensity.

\section{References}

Adhikari, A and Sekhon, M.K. (2014). An economic analysis of land use dynamics in Punjab. International Journal of Advanced Research. 2 (5): 551-560.

Kammar, A and Basvaraja, H. (2012). Structural changes in cropping pattern in Northern transitional zone of Karnataka. International Research Journal of Agricultural Economics and Statistics, 3 (2): 197-201.

Maniyosai, R. and Antony, K. (2015). The Changing land use pattern of Alappuzha district in kerala. The international journal of humanities \& social studies. 2 (6): 10-13.

Meenakshi, R. and Indumathy, R. (2009). Land utilisation and Cropping pattern in Tamil Nadu. Indian Journal of 
Agricultural Economics. 64 (1): 144153.

Ramasamy, C., Balasubramanian, R. and Sivakumar, S.D. (2005). Dynamics of land use pattern with special reference to fallow lands-an empirical investigation in Tamil Nadu. Indian Journal of Agricultural Economics. 60 (4): 629-643.

Takle, P., Veerkar, P.D., Bhosale, S.S. and Malve, D.B. (2007). Dynamics of land use pattern in Maharashtra, India. International Journal of Agriculture Science. 3 (2): 36-39.

Tirlapur, L. N. and Mundinamani, S.M. (2015). An economic analysis on land use and cropping pattern in Dharwad district. International Research Journal of Agricultural Economics and Statistics. 6 (1): 176-181.

\section{How to cite this article:}

Gaikwad, R.A., K.V. Deshmukh and Shelke, R.D. 2018. Land Utilization and Cropping Pattern in Beed District of Maharashtra. Int.J.Curr.Microbiol.App.Sci. 7(10): 2094-2100. doi: https://doi.org/10.20546/ijcmas.2018.710.241 